TECHNICAL PROGRESS REPORT

SHIPPINGPORT ATOMIC POWER STATION (PWR)

for the period

JULY 26, 1979 to JANUARY 25, 1980

\title{
APPROVED :
}

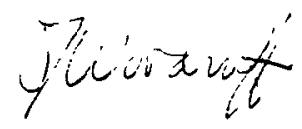

0 . J , WOODRUFF

CONTRACT DE-AC11-76PN00014

PRINTED IN THE UNITED STATES OF AMERICA

AVAILABLE FROM THE NATIONAL TECHNICAL INFORMATION SERVICE

U. S. DEPARTMENT OF COMMERCE

5285 PORT ROYAL ROAD

SPRINGFIELD, VIRGINIA

22151

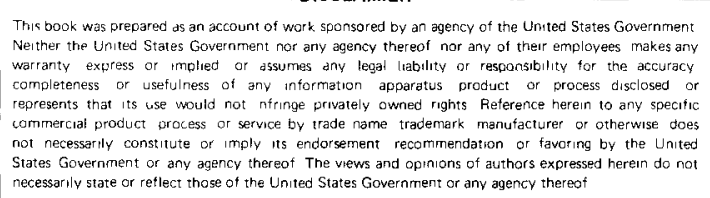

BETTIS ATOMIC POWER LABORATORY - WEST MIFFLIN, PENNSYLVANIA

OPERATED FOR THE U. S. DEPARTMENT OF ENERGY

BY WESTINGHOUSE ELECTRIC CORPORATION 


\section{DISCLAIMER}

This report was prepared as an account of work sponsored by an agency of the United States Government. Neither the United States Government nor any agency Thereof, nor any of their employees, makes any warranty, express or implied, or assumes any legal liability or responsibility for the accuracy, completeness, or usefulness of any information, apparatus, product, or process disclosed, or represents that its use would not infringe privately owned rights. Reference herein to any specific commercial product, process, or service by trade name, trademark, manufacturer, or otherwise does not necessarily constitute or imply its endorsement, recommendation, or favoring by the United States Government or any agency thereof. The views and opinions of authors expressed herein do not necessarily state or reflect those of the United States Government or any agency thereof. 


\section{DISCLAIMER}

Portions of this document may be illegible in electronic image products. Images are produced from the best available original document. 
WAPD-MRP-153

Number of Copies

UC-78: Light Water Reactor Technology, 183 DOE/TIC-4500 (Rev. 67)

SPECIAL EXTERNAL DISTRIBUTION

Deputy Assistant Secretary for Nuclear Waste Management $\quad 1$

Deputy Assistant Secretary for Nuclear Reactors Program 1

Director, Division of Reactor Research and Technology 1

Director, Division of Nuclear Power Development $\quad 1$

Deputy Assistant Secretary for Naval Reactors $\quad 10$

Manager, Pittsburgh Naval Reactors 1

KAPL (Attention: Document Custodian) 3

PAD (Attention: W. D. Miller, General Manager) 3

MAO (Attention: W. Northrup, General Manager) 3

NRC - Advisory Committee on Reactor Safeguards 1

Pennsylvania Bureau of Radiological Health 1

Department of Environmental Resources

$\begin{array}{ll}\text { TOTAL } & 209\end{array}$

\section{NOTICE}

This report was prepared as an account of work sponsored by the United States Government. Neither the United States, nor the United States Department of Energy, nor any of their employes, nor any of their contractors, subcontractors, or their employes makes any warranty, expressed or imp1ied, or assumes any legal liability or responsibility for the accuracy, completeness or usefulness of any information, apparatus, production or process disclosed, or represents that its use would not infringe privately-owned rights. 
WAPD-MRP-153

\section{INTENTIONALLY BLANK}




\section{EOREWORD}

The Shippingport Atomic Power Station located in Shippingport, Pennsylvania, was the first large-scale, central-station nuclear power plant in the United States and the first plant of such size in the world operated solely to produce electric power. This program was started in 1953 to confirm the practical application of nuclear power for large-scale electric power generation. It has provided much of the technology being used for design and operation of the commercial, central-station nuclear power plants now in use.

Subsequent to development and successful operation of the Pressurized Water Reactor in the Atomic Energy Commission (now Department of Energy, DOE) owned reactor plant at the Shippingport Atomic Power Station, the Atomic Energy Commission in 1965 undertook a research and development program to design and build a Light Water Breeder Reactor core for operation in the Shippingport Station.

The objective of the Light Water Breeder Reactor (LWBR) program has been to develop a technology that would significantly improve the utilization of the nation's nuclear fuel resources employing the well-established water reactor technology. To achieve this objective? work has been directed toward analysis, design, component tests, and fabrication of a water-cooled, thorlum oxide-uranium oxide fuel cycle breeder reactor for installation and operation at the Shippingport Station. The LWBR core started operation in the Shippingport Station in the Fall of 1977 and is expected to be operated for about a total of 4 to 5 years. At the end of this period, the core will be removed and the spent fuel shipped to the Naval Reactors Expended Core Facility for a detailed examination to verify core performance including an evaluation of breeding characteristics.

In 1976, with fabrication of the Shippingport EWBR core nearing completion, the Energy Research and Development Administration, now DOE, established the Advanced Water Breeder Applications (AWBA) program to develop and disseminate technical information which would assist $U$. S. industry in evaluating the LWBR concept for commercial-scale applications. The program is exploring some of the problems that would be faced by industry in adapting technology confirmed in the LWBR program. Information being developed Includes concepts for commerclal-scale prebreeder cores which would produce urantum-233 for 1ight water breeder cores while producing electric power, improvements for breeder cores based on the technology developed to fabricate and operate the Shippingport LWBR core and other information and technology to aid in evaluating commercial-scale application of the LWBR concept.

A11 three development programs (Pressurized Water Reactor, Light Water Breeder Reactor, and Advanced Water Breeder Applications) are under the technical direction of the Naval Reactors Program of DOE. They have the goal of developing practical improvements in the ut1lization of nuclear fuel resources for generation of electrical energy using water-cooled nuclear reactors.

Technical information developed under the ShIppingport, LWBR, and AWBA programs has been and wi11 continue to be published. 


\section{TABLE OF CONTENTS}

\section{Title}

Highlight Summary

A. Shippingport Station Operations...................... 1

1. Plant Evolutions.............................. 1

2. Evaluation of Core Test Data...................... 1

a. Nuclear Data............................... 1

(1) Periodic Physics Testing..................... 1

(2) Monitoring Core Performance................. 3

b. Thermal and Hydraulic Evaluation................. 3

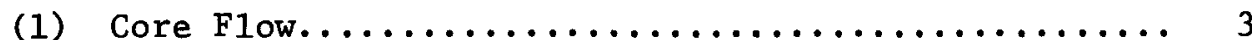

(2) Movable Fue1 Scram Characteristics............. 5

c. Control Drive Mechanism Testing................ 5

3. Support of Operations........................ 6

B. Plant Modification............................. 6

C. Plant Maintenance............................... 6

D. Training.................................... 8

E. Shipment of PWR Core 2 Components from the Shippingport Atomic

Power Station................................. 8

F. Primary Plant Water Chemistry,.................... 8

1. Month1y Operational Data....................... 8

2. Primary Coolant Chemistry Test Data.................. 9

a. Periodic Radiochemical Analysis of Reactor Coolant...... 9

b. Reactor Coolant Fission Product Monitoring During

Reactor Startup........................... 9

G. LWBR Core Defueling and Shipping Program................ 25

H. LWBR Core Evaluation at ECF....................... 25

Appendix A - LWBR Core Parameters...................... A-1 
WAPD-MRP-153

\section{HIGHLIGHT SUMMARY}

The Shippingport Atomic Power Station was operated with the Light Water Breeder Reactor core at high power levels (base load) throughout this report period except for reductions in power or brief shutdowns to perform planned testing. Evaluation of core test data taken during this period continues to show that the core is operating in accordance with design predictions.

Periodic flow coefficient of reactivity measurements are reported which all meet the criteria on which the revised core protection setpoints and station operating procedures (see WAPD-MRP-152) were based.

The core achieved 14,343 EFPH* at the end of the period after exceeding one billion kilowatt hours total gross electrical output on December 11, 1979.

* EFPH = Equivalent Full Power Hours (where full power is defined as $236.6 \mathrm{MW}(\mathrm{t})$ ) 


\section{A. Shippingport Station Operations}

1. P1ant Evolutions

At the beginning of the report period, the LWBR core had accumulated 10,834 EFPH. The Station operated at near full power except for periods of lower power operation, maintenance discussed below or brief shutdowns to perform planned testing, achieving 14,343 EFPH on January 25,1980 . Station operation with the LWBR core achieved one billion kilowatt hours total gross electrical output on December 11, 1979. A small leak was detected in a valve ventt line on one of the coolant loops on September 25, 1979. . This loop was isolated and operations continued with 3 loops in service while preparations were made to repair the leak. After a Station shutdown on October 2, 1979, the leak was repaired and satisfactorily retested and the plant was returned to full power operation on October $17,1979$.

\section{Evaluation of Core Test Data}

a. Nuclear Data

\section{(1) Periodic Physics Testing}

During this period, periodic measurements of the flow coefficient of reactivity were performed. These tests were designed to monitor the magnitude of the flow coefficient which was previously reported as being higher than determined in previous testing. Following operation at power, the reactor was shutdown to a power level low in the intermediate range. The critical position with 4-FAST speed pumps operating was measured followed by a bank worth measurement. The flow coefficient (dynamic) was measured by turning off a reactor coolant pump while near critical and observing the resulting reactivity change using the Inverse Kinetics Simulator. The critical position was measured with 3-FAST speed pumps operating. Comparison of the 4-FAST and 3-FAST speed pump critical positions gives another determination of the flow coefficient (static).

Results of periodic flow coefficient measurements are presented in Table 1. These results all meet the criteria on which the revised core protection setpoints and station operating procedures (see WAPD-MRP-152) were based. The criteria require continued periodic testing to monitor any changes in the flow coefficient of reactivity as the core is depleted. 
Tab1e 1

Summary of Periodic Flow Coefficient Measurements

\section{Measurement Type}

Initial - Static

First Periodic - Static

First Periodic - Static

Second Periodic - Static

Second Periodic - Dynamic

Third Periodic - Static

Third Periodic - Dynamic

Fourth Periodic - Static

Fourth Periodic - Dynamic

Fifth Periodic - Static

Fifth Periodic - Dynamic

Sixth Periodic - Static

Sixth Periodic - Dynamic

\section{4-FAST to 3-FAST}

Date

$7 / 22 / 79$

$7 / 31 / 79$

$7 / 31 / 79$

$8 / 14 / 79$

$8 / 14 / 79$

$9 / 14 / 79$

$9 / 14 / 79$

$11 / 2 / 79$

$11 / 2 / 79$

$12 / 12 / 79$

$12 / 12 / 79$

$1 / 9 / 80$

$1 / 9 / 80$
Bank Worth $\left(10^{-4} \Delta \rho /\right.$ inch $)$

0.21

0.23

0.16

0.20

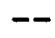

0.16

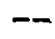

0.16

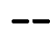

0.14

$-$

0.12

$--$
28,73

23.53

25.32

21.67

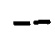

22.68

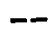

23.35

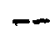

21.94

$-$

20.92

$--$
Flow Coefficient

(10-4 هp/East speed pump)

6.03

5.41

4.05

4.33

4.28

3.62

4.77

3.74

4.02

3.07

3.57

2.51

2.90 
A.2.a.

(2) Monitoring Core Performance

Figure 1 presents a plot of Movable Fuel Assembly Bank positions versus lifetime. The upper curve is the as-built calculated fuel position as a function of EFPH, which is based on assumed continuous full power operation. The series of circles are inferred positions obtained by adjusting the measured fuel positions to account for differences in observed conditions from conditions appropriate to the full power PDQ depletion calculation. The data indicate that the core at ful1 power is overreactive by $0.36 \% \Delta \rho$ relative to the 3-D PDQ calculations which have been corrected for time step depletion effects. The indicated value is well within the core design range of reactivity $( \pm 1 \% \Delta \rho)$.

The lower curve is the calculated hot, zero power critical position with xenon decayed out. The boxed data points are the measured critical positions following shutdown of at least 90 hours adjusted for differences in $\mathrm{Pa}-233$ and Sm-149 between the detailed power history depletion and a base case depletion. These data indicate that the core, at zero power and xenon free, was overreactive by $0.25 \% \Delta \rho$ relative to design calculations at 12,301 EFPH with $41 \%$ of ful1 power equilibrium $\mathrm{Pa}-233$. The indicated value is well within the core design range of reactivity uncertainty $( \pm 1 \% \Delta \rho)$.

Figure 1 shows a discontinuity at about 11,000 EFPH in the trend of the circles representing fuel positions. This discontinuity is thought to be caused by reactivity changes ascribed to the radial motion of the fuel modules in their clearances (discussed in WAPD-MRP-152, Section A.2.a.1.) and the noted change in the flow coefficient of reactivity.

b. Thermal and Hydraulic Evaluation

\section{(1) Core Flow}

The LWBR core flow distribution and core and balance piston pressure differentials are monitored on a continuous basis. Flows are measured in seven seed modules and six blanket modules. Pressure differentials are measured across the core. The measured data remain within the predicted range as shown in Table 2 . On the average, flow values are about 1 to $2-1 / 2 \%$ less than the initial startup data and core pressure drop is about $4-5 \%$ higher, as expected due to deposition of crud in the core. Core hydraulic performance has been satisfactory during the current operating period. 


\section{FIGURE 3. LWBR CORE MOVABLE FUEL POSITION VERSUS LIFETIME}

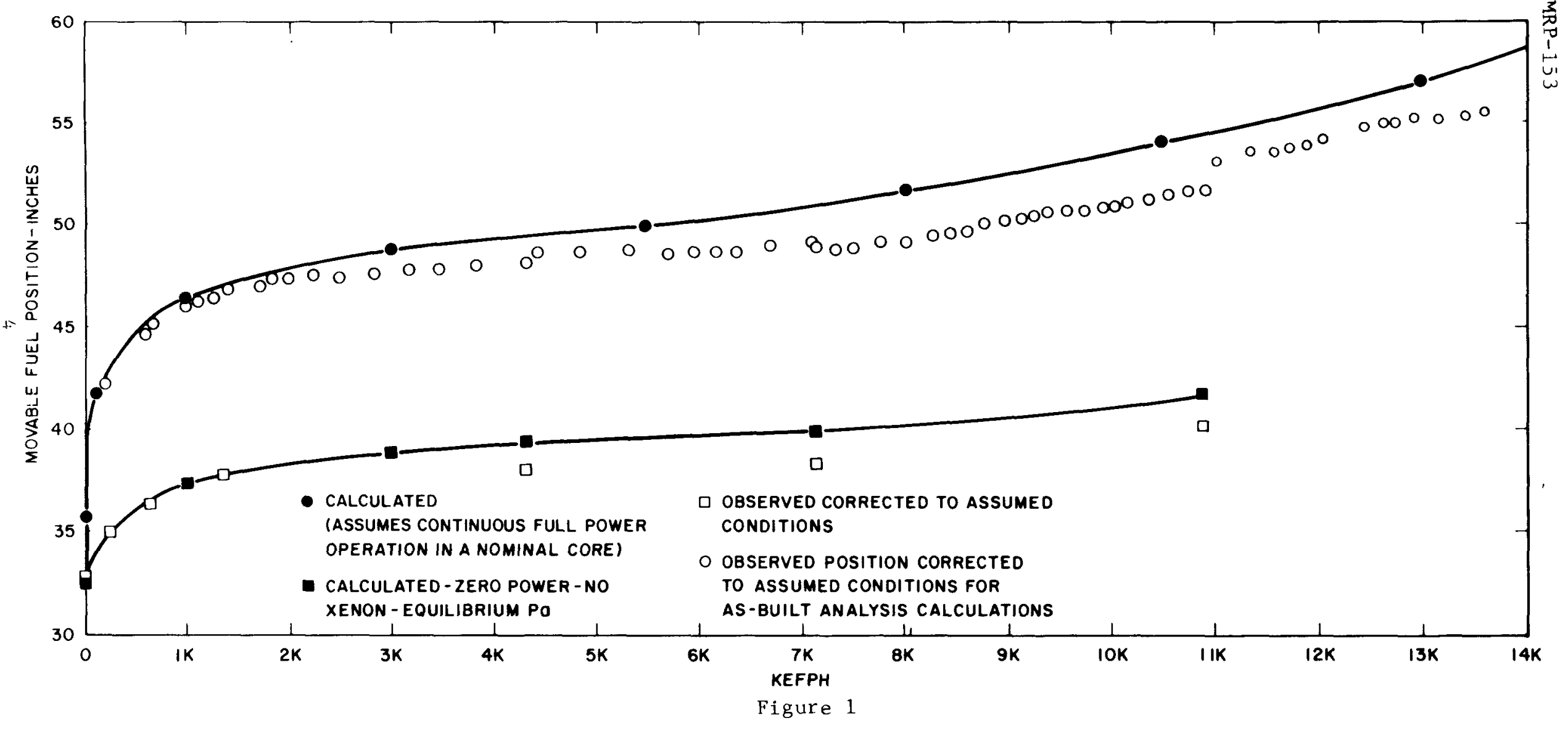


$\underline{\text { Table } 2}$

Comparison of Measured Core Flows and Pressure Drops with Allowable Ranges

(Operation at Fu11 Flow and Power)

\begin{tabular}{lll} 
& \multicolumn{1}{c}{$\begin{array}{l}\text { Measured } \\
\text { Range }\end{array}$} & $\begin{array}{l}\text { Predicted } \\
\text { Range }\end{array}$ \\
Seed Flow (1b./sec.) & $184.2-200.7$ & $164.0-212.6$ \\
Blanket Type I Flow (1b./sec.) & $261.5-275.9$ & $247.0-290.0$ \\
Blanket Type II Flow (1b./sec.) & $453.2-472.1$ & $404.0-491.0$ \\
Blanket Type III Flow (1b./sec.) & $547.4-585.0$ & $505.5-585.0$ \\
Core Pressure Drop (psi) & $48.0-52.0$ & $38.8-58.0$ \\
Balance Piston Pressure Drop (psi) & $44.7-47.5$ & $4 I .8-47.9$
\end{tabular}

(2) Movable Fue1 Scram Characteristics

Scram characteristics for each of the 12 movable fuel assemblies were measured during September. The terminal scram velocities ranged from 11.0 to 12.6 inches per second (ips). These data are in good agreement with the expected range of 9 to 16 ips and the precritical measured data range of 11.4 to 13.0 ips. Similarly, the bottom-stop contact velocities ranged from 1.3 to 1.9 ips which are also in good agreement with the expected range of .5 to 4 ips and the precritical measured data range of .8 to 1.7 ips. Monitoring of movable fuel assembly motion as shown by the above data confirms that scram performance remains satisfactory.

c. Control Drive Mechanism Testing

The periodic testing of the Control Drive Mechanisms was performed in September 1979. All operating characteristics measured in accordance with the test procedure were within the expected ranges and consistent with previous measurements. It is therefore concluded that the mechanisms are operating properly. 
WAPD-MRP-153

A. 3. Support of Operations

The reactor plant was operated on base load throughout this six-month period. Therefore, the number of swingload cycles used to demonstrate load follow capability remains at 154 cycles as reported in

WAPD-MRP-152. Fuel rod integrity has been maintained as indicated by the continuing low level of radioactivity measured in the reactor coolant.

Control of plant operations to avoid high cladding stresses in the fuel rods which could lead to stress corrosion cracking or mechanical rupture of the cladding is provided by a comparison of the Lifetime Equivalency Parameter (LEP) to the minimum allowable level (DLEP). The method used by the reactor operator to calculate LEP and its use in comparison with the DLEP curves are described in the earlier reports in this series (WAPD-MRP-149, 150 and 151). The set of LEP plots and DLEP curves used by the operator are shown in Figure 2.

The operator-calculated LEP is used by station operating personnel to compare with the DLEP and thus to determine the need for restricted operations to protect fuel rod clad integrity. As long as the reactor power history permits the LEP to remain above the operating DLEP, routine operations to full power are permitted. If the power history were to cause the LEP to fall to the curve labeled Setpoint DLEP, core protection setpoints would have to be changed to protect the cladding from postulated accidents during any power operations. The broken line in Figure 2 shows the LEP calculated monthly through December 1979 on the basis of maximum cladding stresses. The stress-based LEP is independently calculated by Bettis to verify the operator-calculated LEP.

The LEP comparisons to the DLEP curves indicate satisfactory margins for power maneuvering to full rated power and for postulated power transients to peak module overpower levels.

\section{B. P1ant Modification}

No significant plant modifications were made in this report period.

\section{Plant Maintenance}

Investigation of a spurious alarm for a redundant emergency power system identified a malfunctioning overcurrent relay. Preventive maintenance was performed on December 18, 1979 on all similar relays of the Emergency Power System using vendor instructions and equipment. Thirty percent of the overcurrent relays falled the acceptance test due to excessive forward leakage current of the output circuit silicon controlled rectifiers. The questionable rectifiers were replaced and all overcurrent relays were satisfactorily tested. 


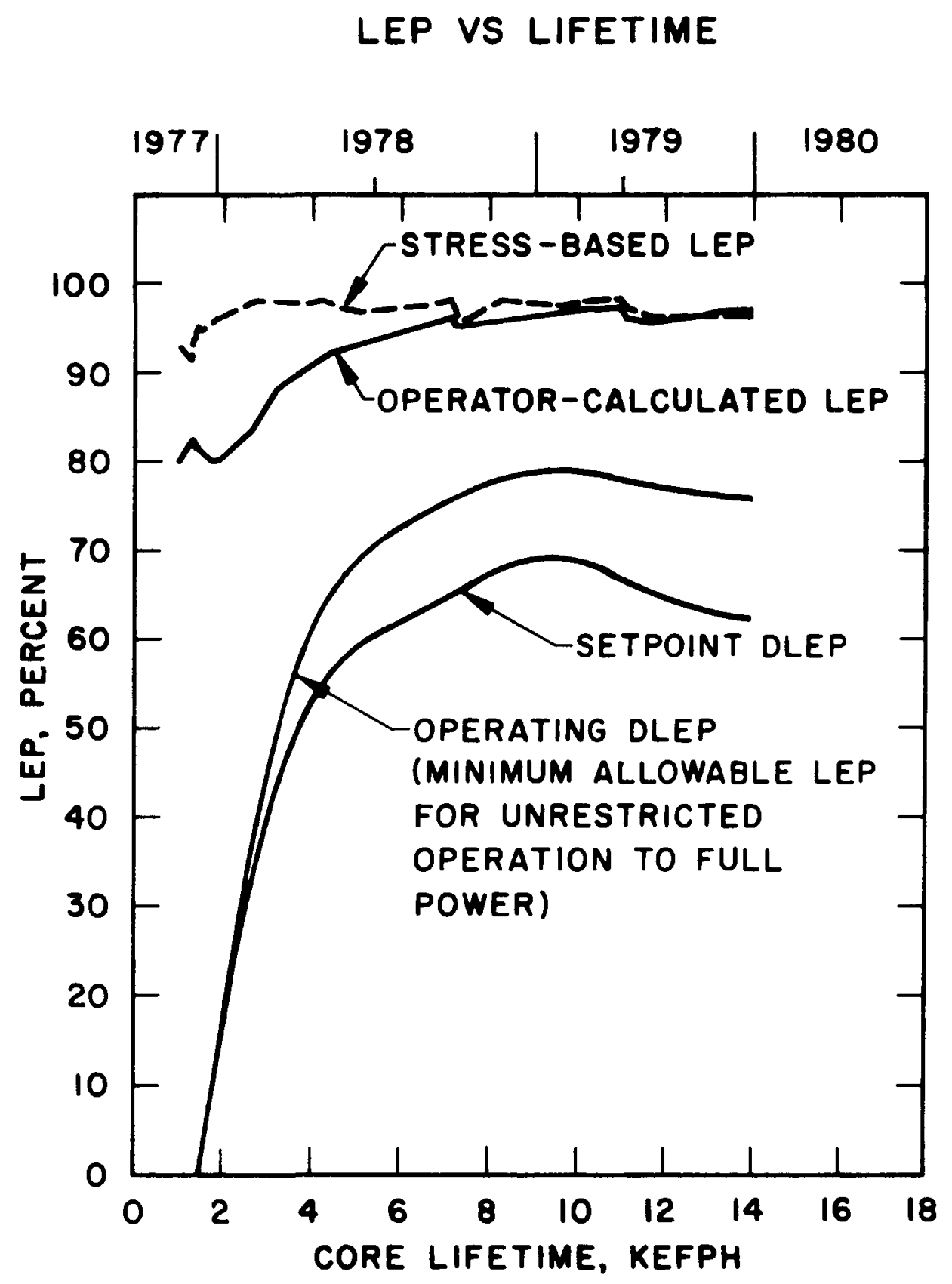

FIGURE 2 
WAPD-MRP-153

\section{Training}

The continuous retraining of DOE certified operations personnel and the precertification training of replacement personnel has continued in accordance with the overall plan for such training during the LWBR operating and defueling period.

E. Shipment of PWR Core 2 Components from the Shippingport Atomic Power Station

The PWR Core 2 upper and lower core barrels were separated in preparation for shipping the upper core barrel for burial. (The lower core barrel will be shipped separately.) Fabrication of the upper core barrel shipping container was initiated. Shipment of the upper barrel is scheduled to begin in the next report period.

F. Primary Plant Water Chemistry

1. Month1y Operational Data

Figures 3 through 17 present reactor plant primary coolant chemistry data for the six month period from July through December 1979. The $\mathrm{pH}$, conductivity, total gas and hydrogen levels measured throughout this period are depicted in Figures 3 through 8 . After $\mathrm{NH}_{4} \mathrm{OH}$ additions, $\mathrm{pH}$ and conductivity levels immediately increase, then decrease, as expected, with operations. Ammonium hydroxide additions are required to maintain coolant $\mathrm{pH}$ between 10.10 and 10.30. During this period there was one instance of an out-ofspecification $\mathrm{pH}$ level of 10.05* on August 7, 1979. The $\mathrm{pH}$ was quickly brought back within specification by the addition of $\mathrm{NH}_{4} \mathrm{OH}$ (see Figure 4). Conductivity levels were consistent with the $\mathrm{pH}$ measurements.

Total gas and hydrogen levels immediately decrease after degasification then increase with operations. Plant degasification is required to maintain the total gas below $125 \mathrm{cc} / \mathrm{kg}$ and the hydrogen between 10 and $60 \mathrm{cc} / \mathrm{kg}$. All total gas levels were within specification during the entire period. However, there were several instances of high hydrogen concentrations. No corrective action was required. If coolant hydrogen gas concentrations exceed $60 \mathrm{cc} / \mathrm{kg}$, degasification need not be employed to reduce the hydrogen unless the total gas exceeds $125 \mathrm{cc} / \mathrm{kg}$.

Degassed gross beta activity levels, extrapolated to full power, and visual crud concentrations in the reactor primary coolant are presented in Figures 9 through 14. The degassed gross beta

*The out-of-specification condition was of short duration and is not expected to have had a detrimental effect on plant materials. 
F.1 measurements are made during all periods of reactor power operations. These data are consistent with normal operating ranges, do not exhibit any unusual levels or trends, and continue to confirm low LWBR reactor coolant activity levels. There were a few isolated instances of above normal (but $\leq 25 \mathrm{ppb}$ ) effluent visual crud concentrations measured during this period. Effluent visual crud concentrations must exceed $12 \mathrm{ppb}$ for a period of three weeks before action is required. No consistently high effluent trends were in evidence and no corrective action was required.

During this six month period, 37 sets of fission product iodine measurements were made, see Figures 15,16 and 17 . These weekly gross iodine, iodine-131, and iodine-133 measurements, normalized to $100 \%$ power, are consistent with previous results. In addition, revisions to the computer program input, used to predict fission product buildup over core life, were made. As a result, a best fit of the measured fission product data through $13,000 \mathrm{EFPH}$ is obtained with a $2.0 \mathrm{ppm} \mathrm{N}_{U}$ contamination level in the core zircaloy cladding vice $1.3 \mathrm{ppm}$ inferred from initial startup data. This $2.0 \mathrm{ppm}$ value is considered acceptable agreement with uranium contamination levels measured in core tubing and is within the range of fission product measurements made at LWBR startup.

\section{Primary Coolant Chemistry Test Data}

Periodic primary coolant chemistry tests are conducted at Shippingport after startup according to the following sequence: (a) radiochemical analysis of primary coolant is performed semi-annually after a startup, and (b) fission product monitoring is performed after each startup.

\section{a. Periodic Radiochemica1 Analysis of Reactor Coolant}

The fourth performance of the periodic radiochemical analysis of reactor coolant was performed from August to December 1979. These data have been received and an evaluation will be completed during the next six-month period.

b. Reactor Coolant Fission Product Monitoring During Reactor Startup

This test is performed during all startups to confirm no defects exist in LWBR core fuel rod cladding. The test was performed eight times during this period. Results of all test evaluations completed to date provide no indication of defective fuel rods in the LWBR core. 
LWBR REACTOR COOLANT CHEMISTRY FOR JULY, 1979

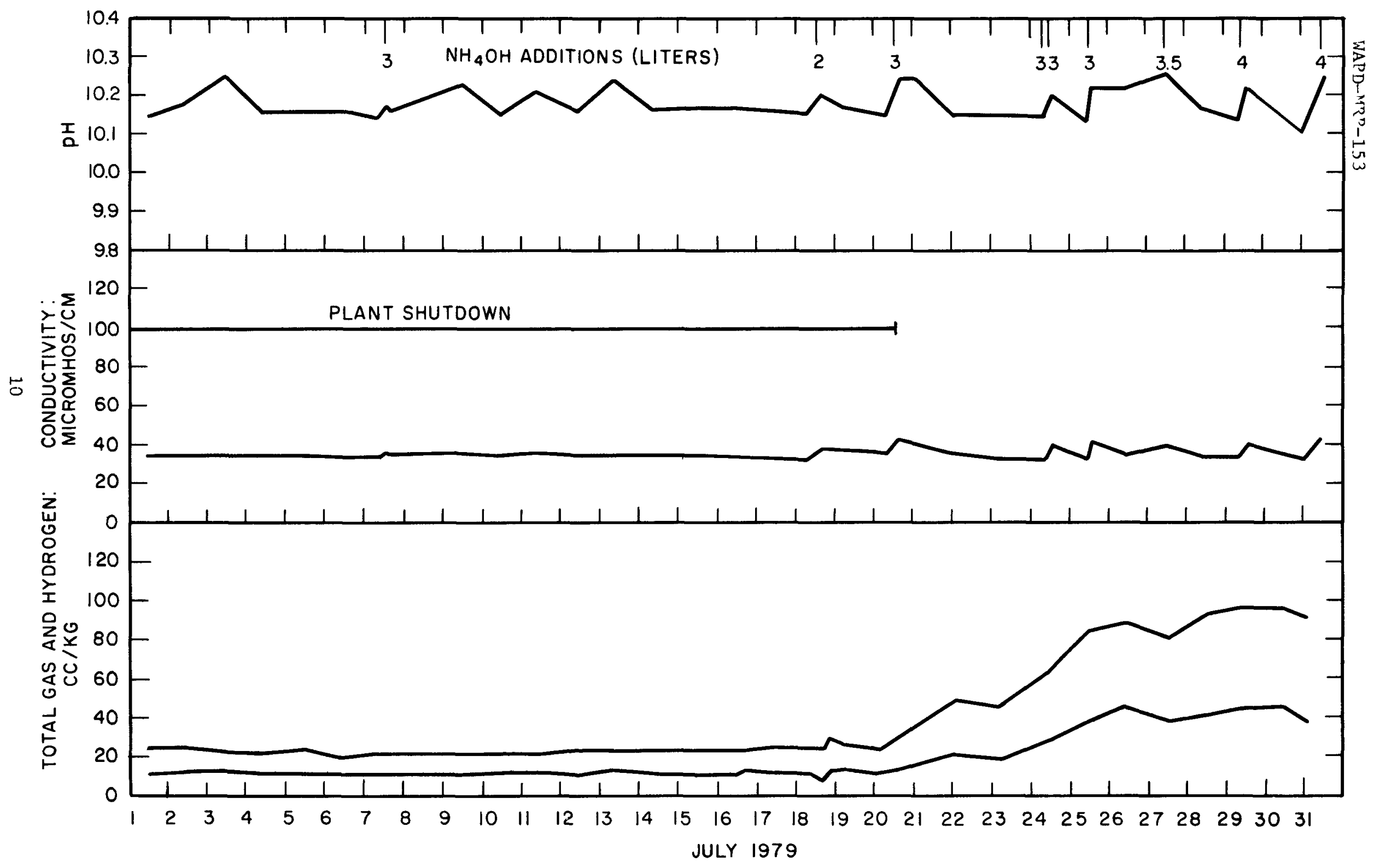

Figure 3 
LWBR REACTOR COOLANT CHEMISTRY FOR AUGUST, 1979

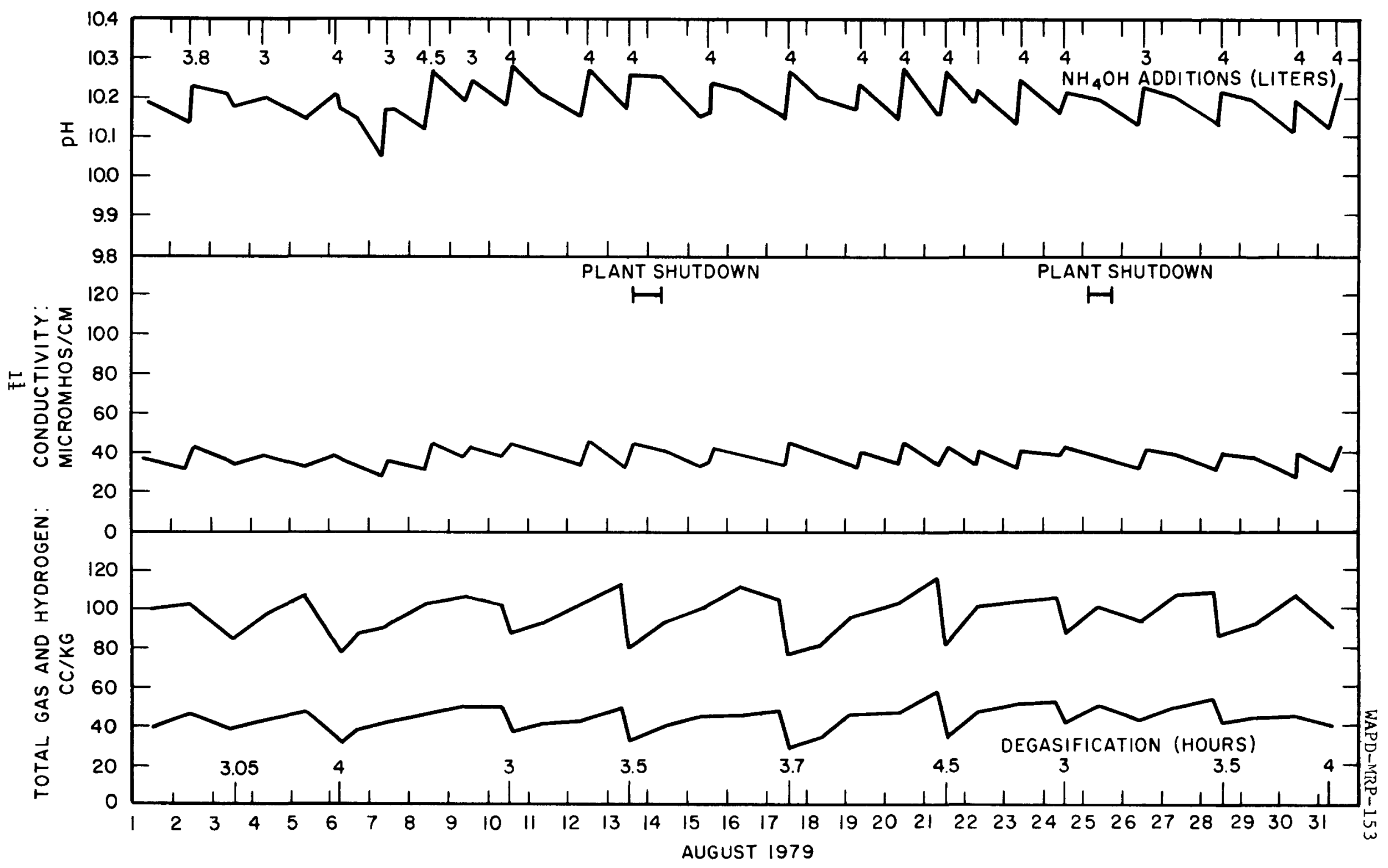

Figure 4 
LWBR REACTOR COOLANT CHEMISTRY FOR SEPTEMBER, 1979

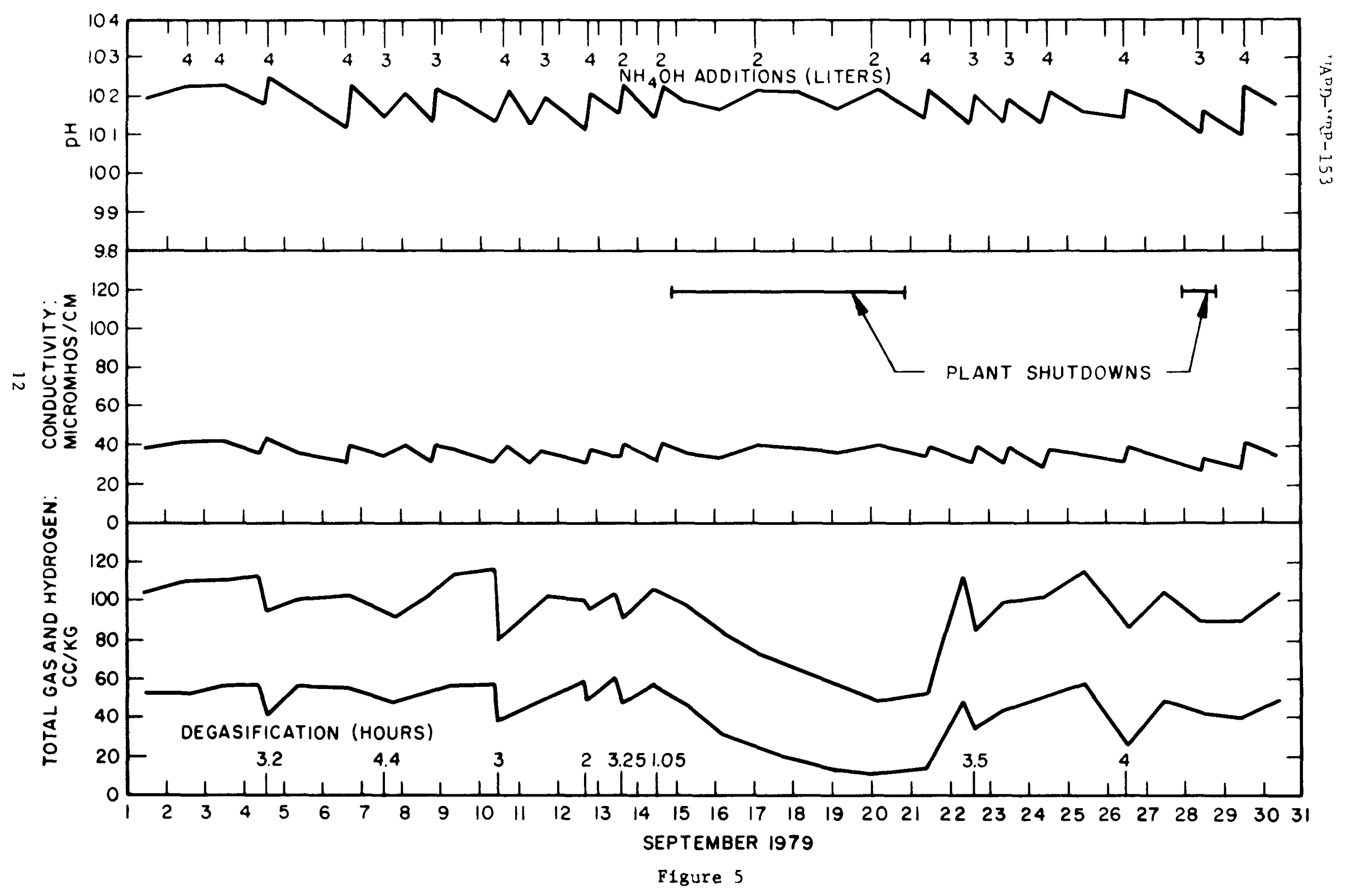


LWBR REACTOR COOLANT CHEMISTRY FOR OCTOBER 1979

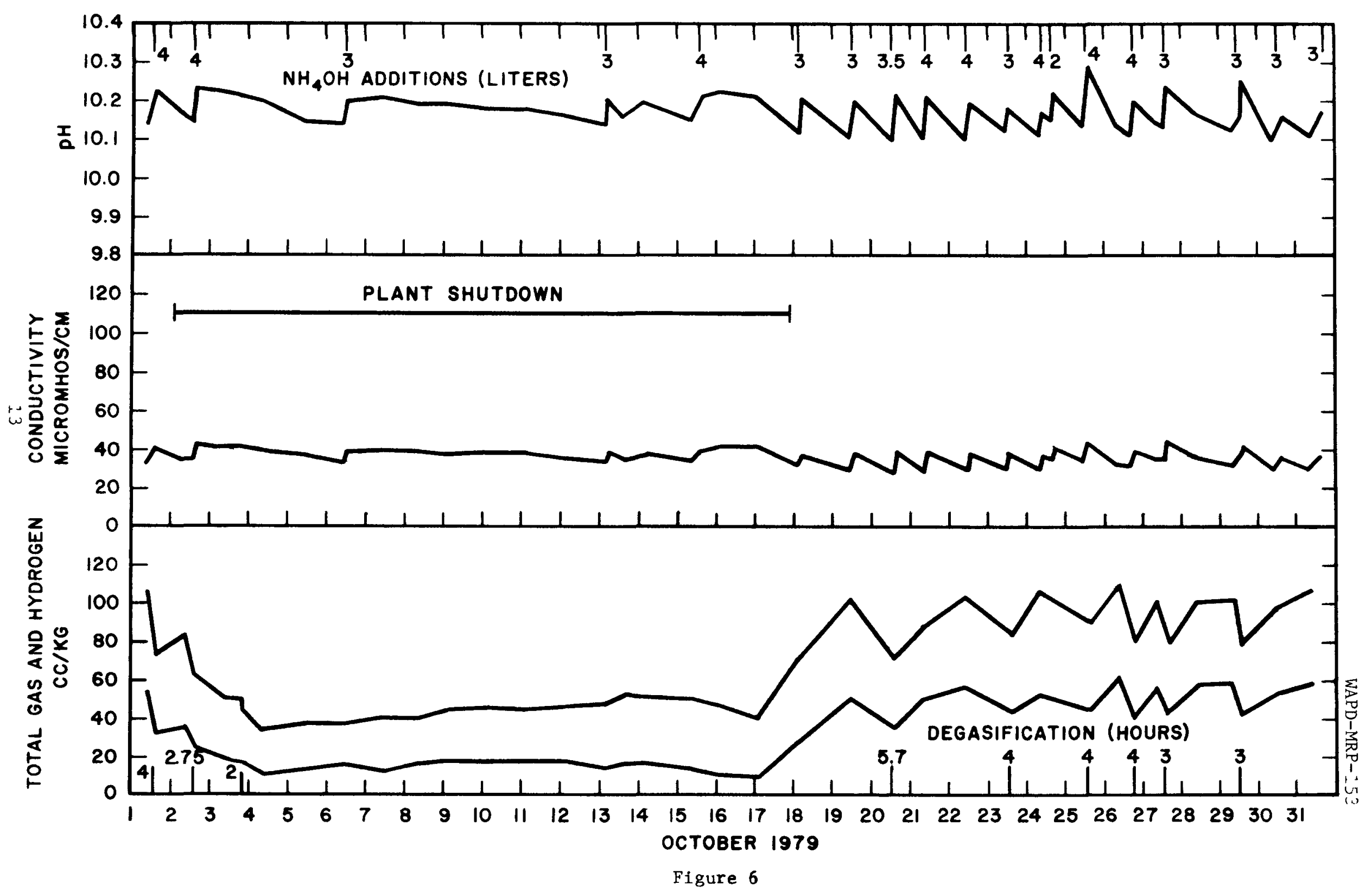


LWBR REACTOR COOLANT CHEMISTRY FOR NOVEMBER, 1979

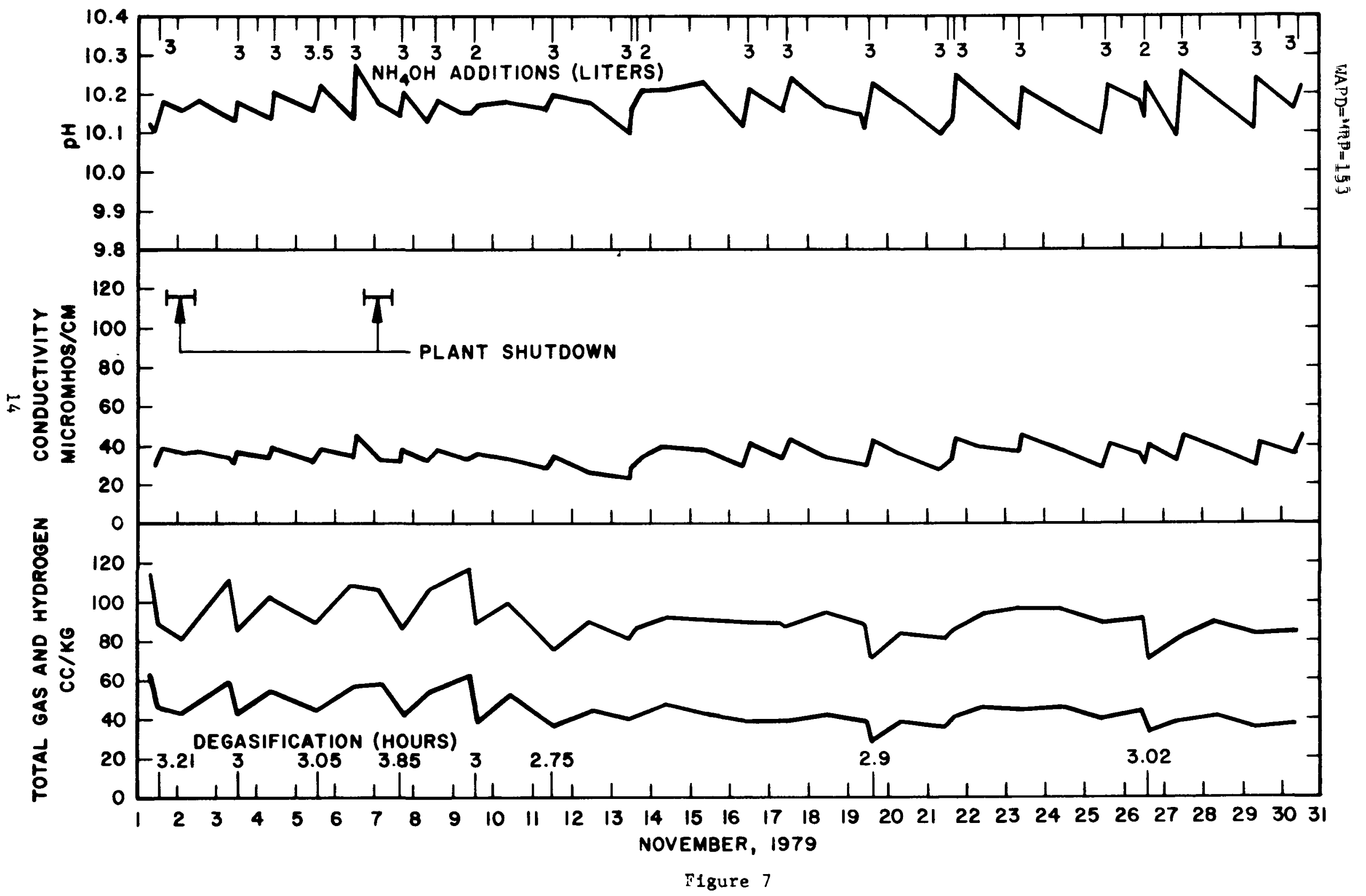


LWBR REACTOR COOLANT CHEMISTRY FOR DECEMBER, 1979

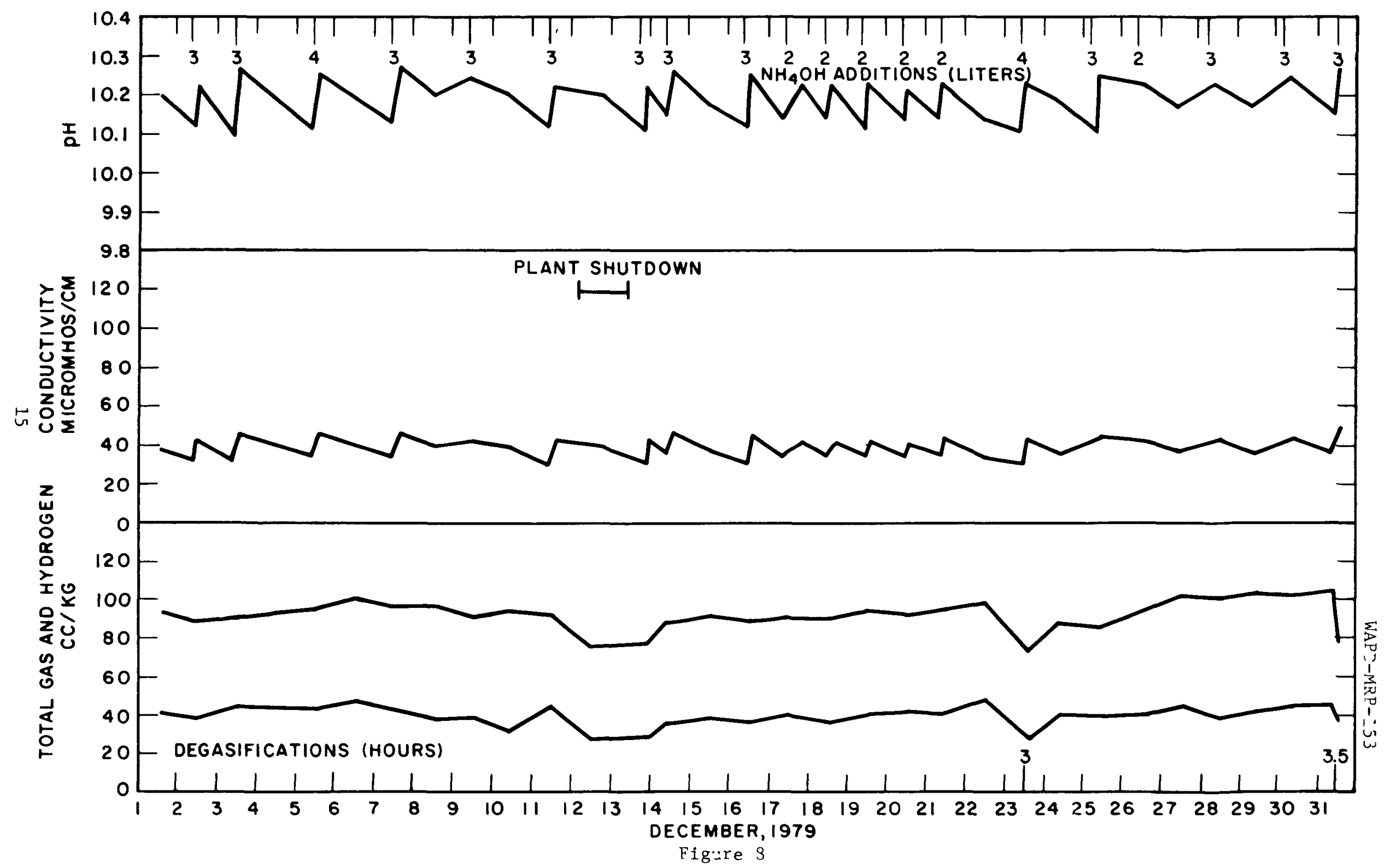


LWBR REACTOR COOLANT DEGASSED GROSS BETA ACTIVITY AND CRUD LEVELS FOR JULY, 1979

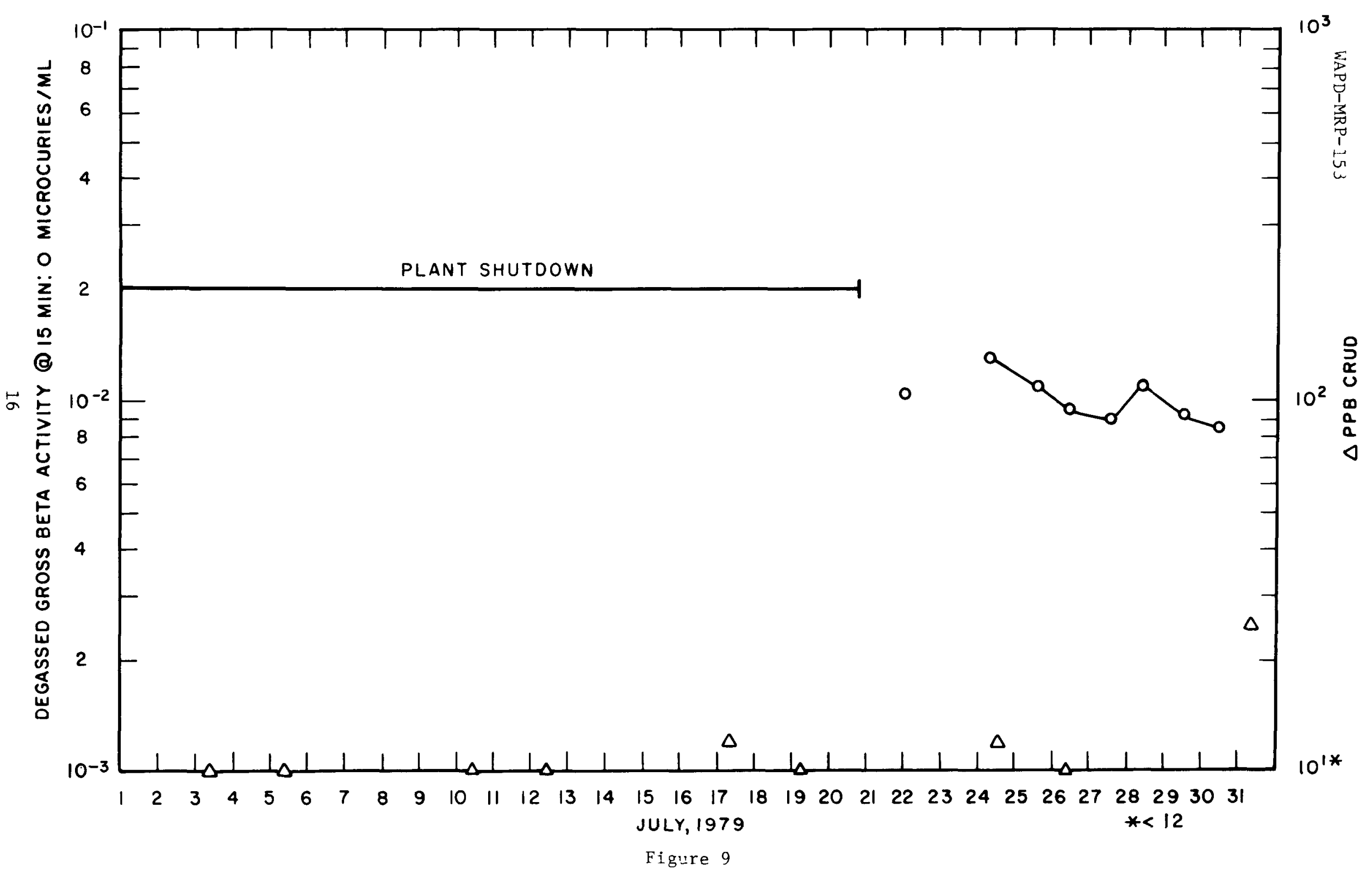


LWBR REACTOR COOLANT DEGASSED GROSS BETA ACTIVITY AND CRUD LEVELS FOR AUGUST, 1979

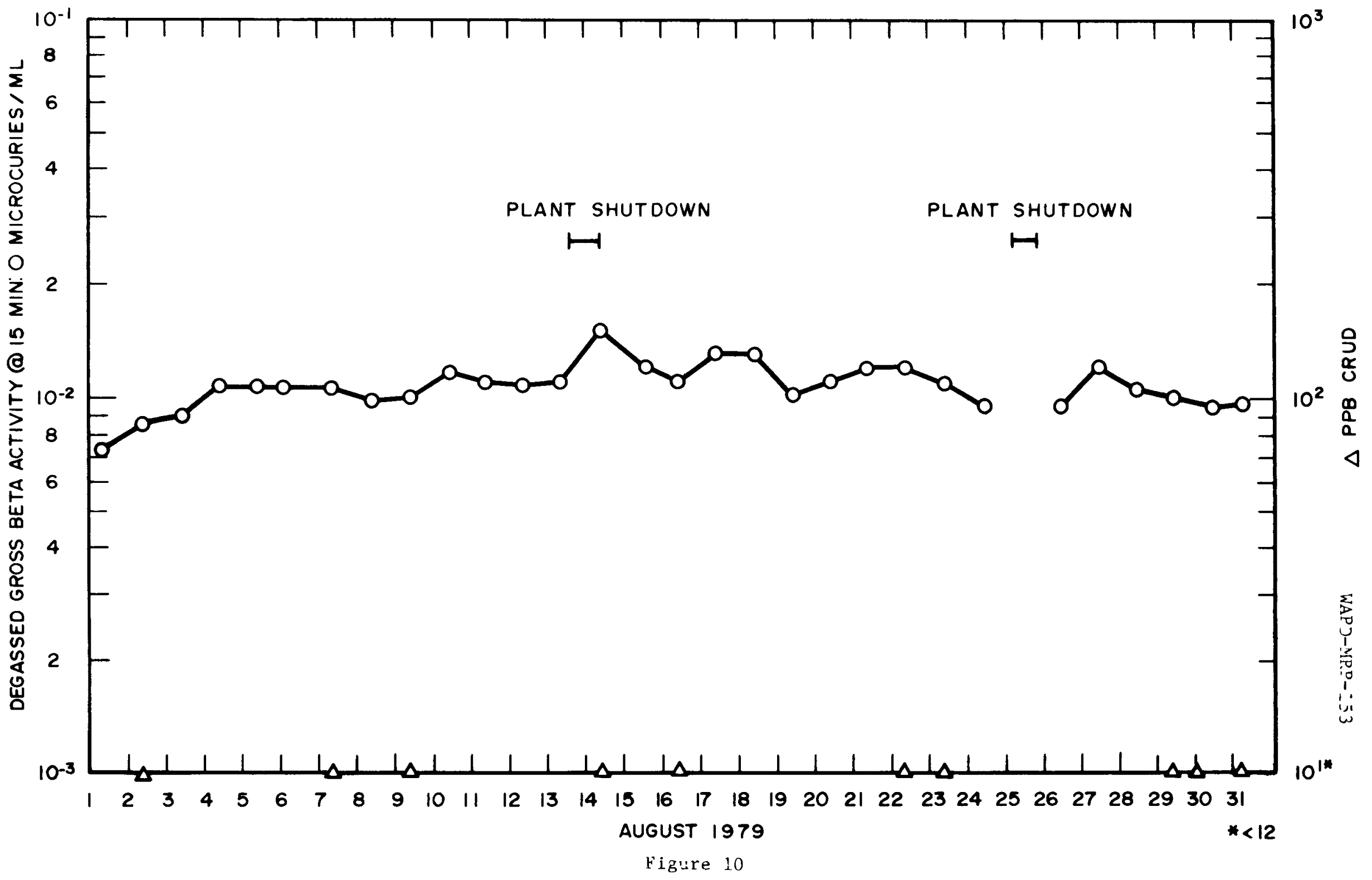


LWBR REACTOR COOLANT DEGASSED GROSS BETA ACTIVITY AND CRUD LEVELS FOR SEPTEMBER,I9T9

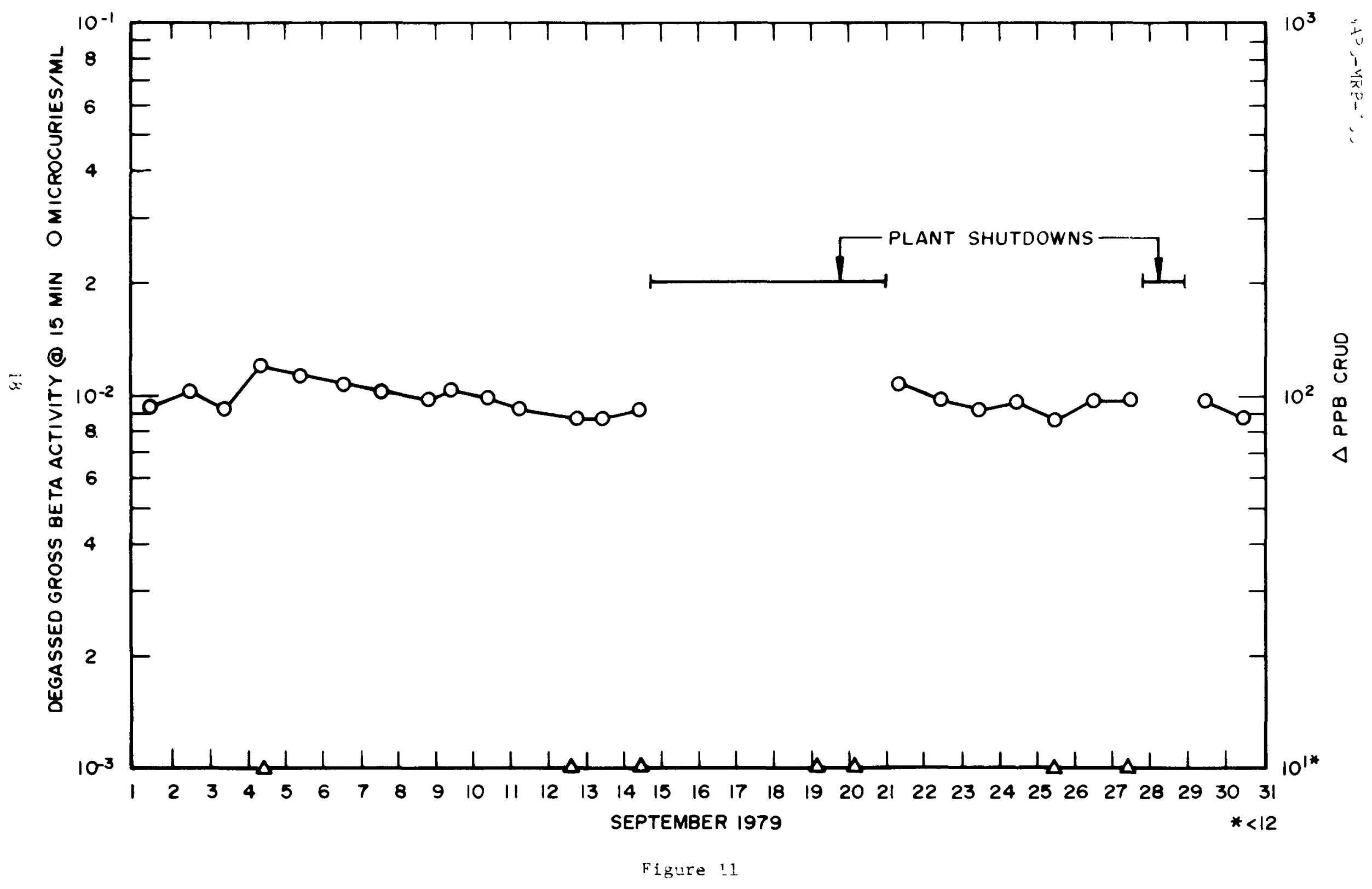


LWBR REACTOR COOLANT DEGASSED GROSS BETA ACTIVITY AND CRUD LEVELS FOR OCTOBER, 1979

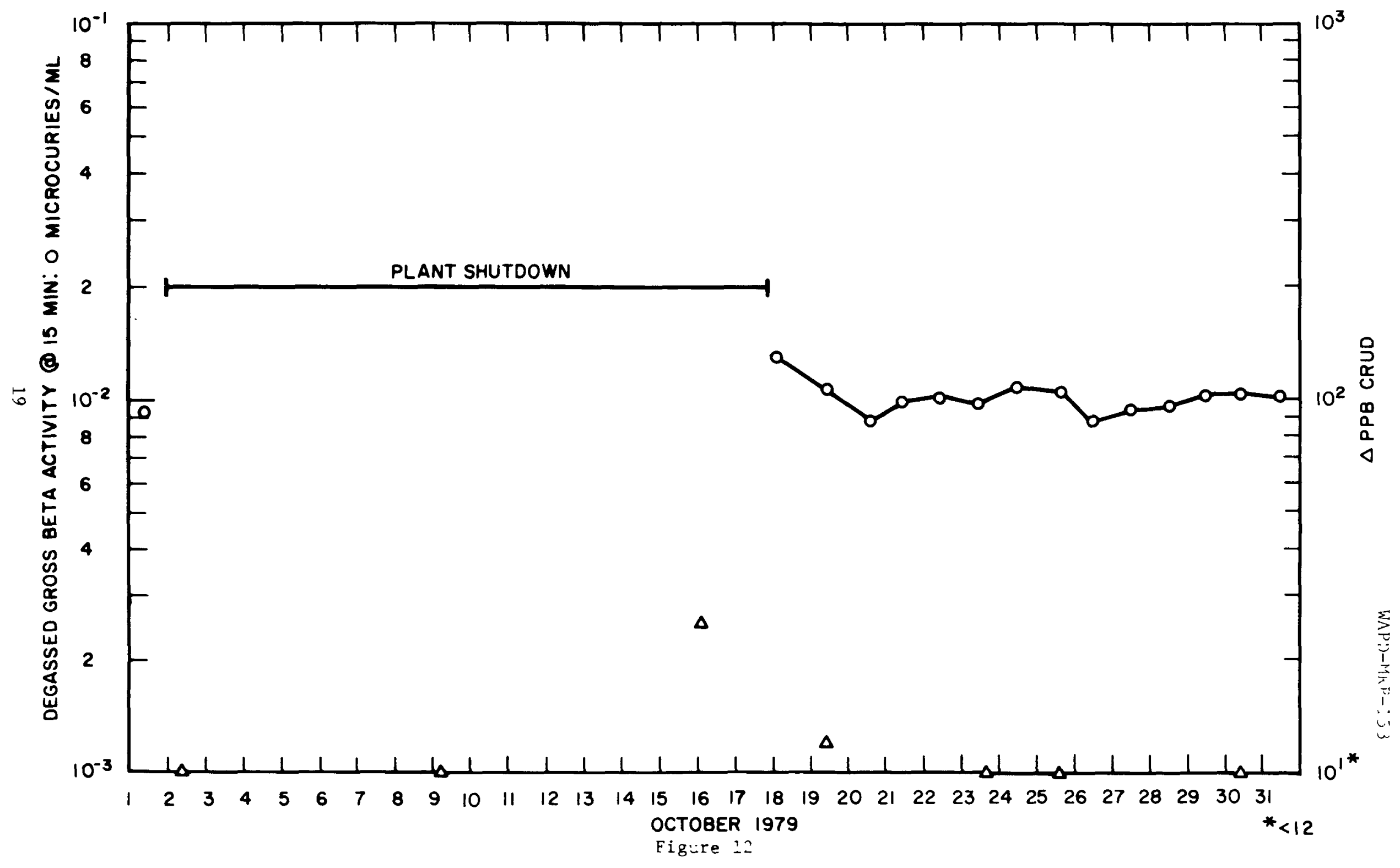


LWBR REACTOR COOLANT DEGASSED GROSS BETA ACTIVITY AND CRUD LEVELS FOR NOVEMBER, 1979

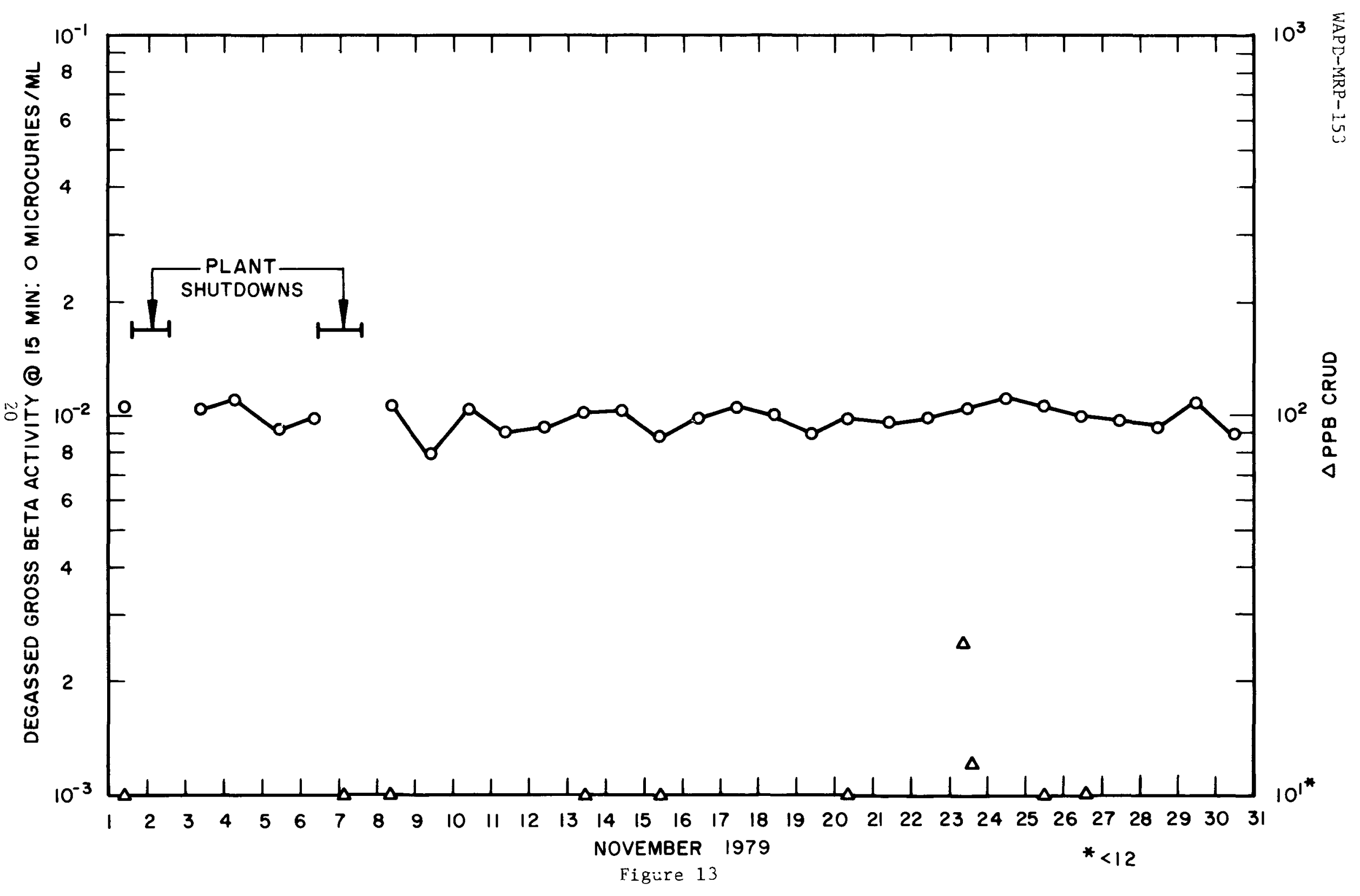


LWBR REACTOR COOLANT DEGASSED GROSS BETA ACTIVITY AND CRUD LEVELS FOR DECEMBER, 1979

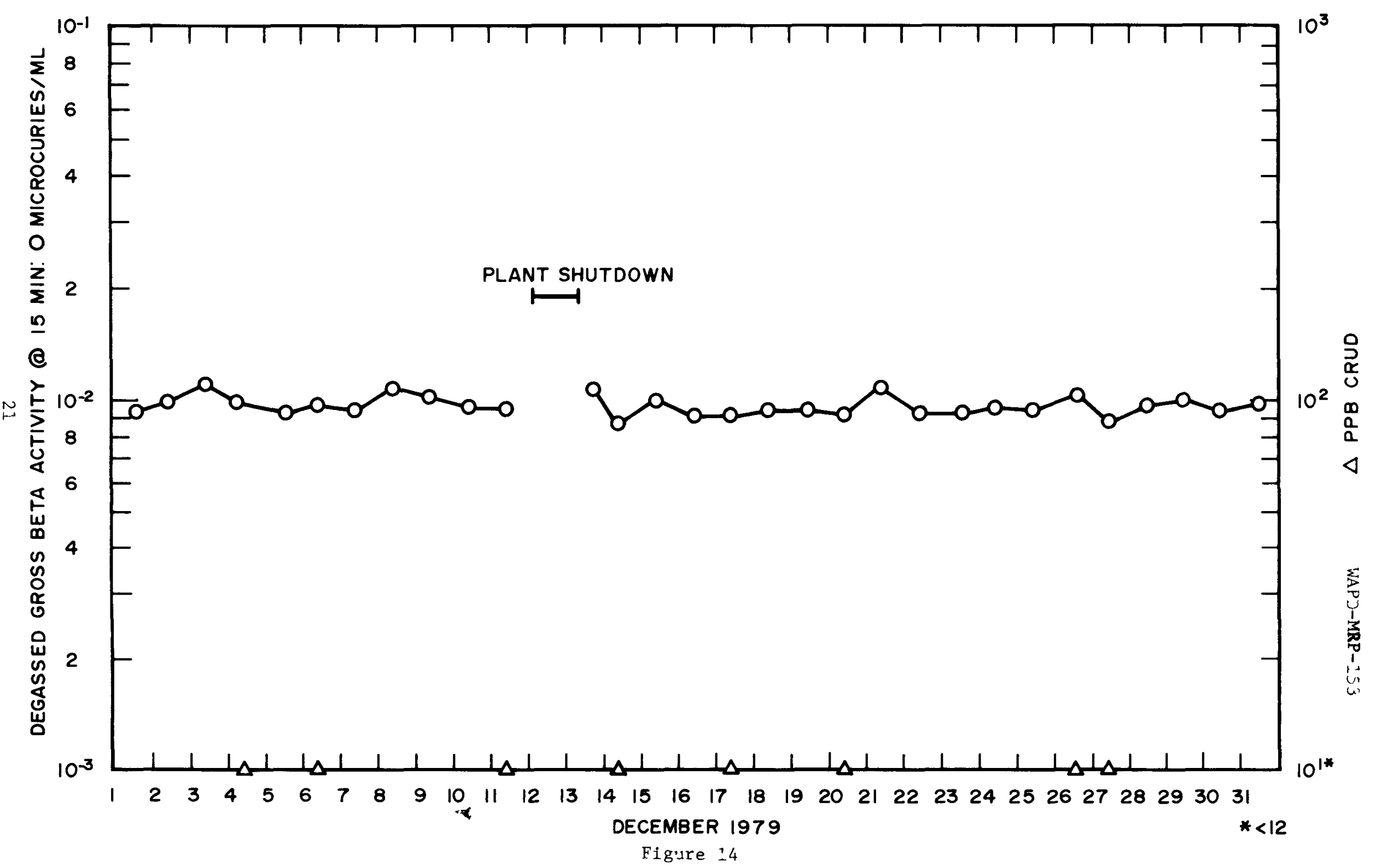


LWBR ONE-HOUR GROSS IODINE ACTIVITY AS A FUNCTION OF CORE DEPLETION

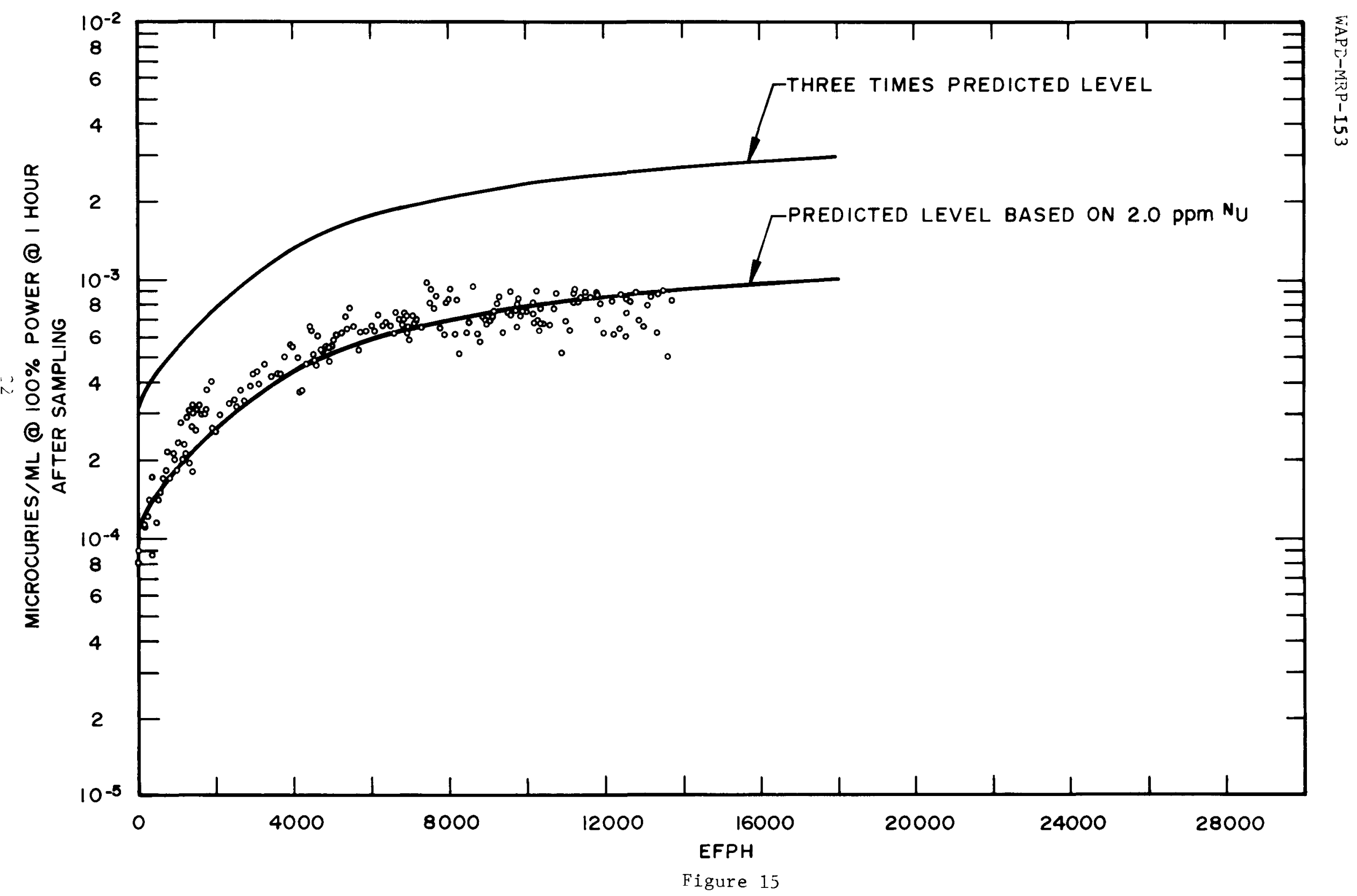


LWBR IODINE-I3I ACTIVITY AS A FUNCTION OF CORE DEPLETION

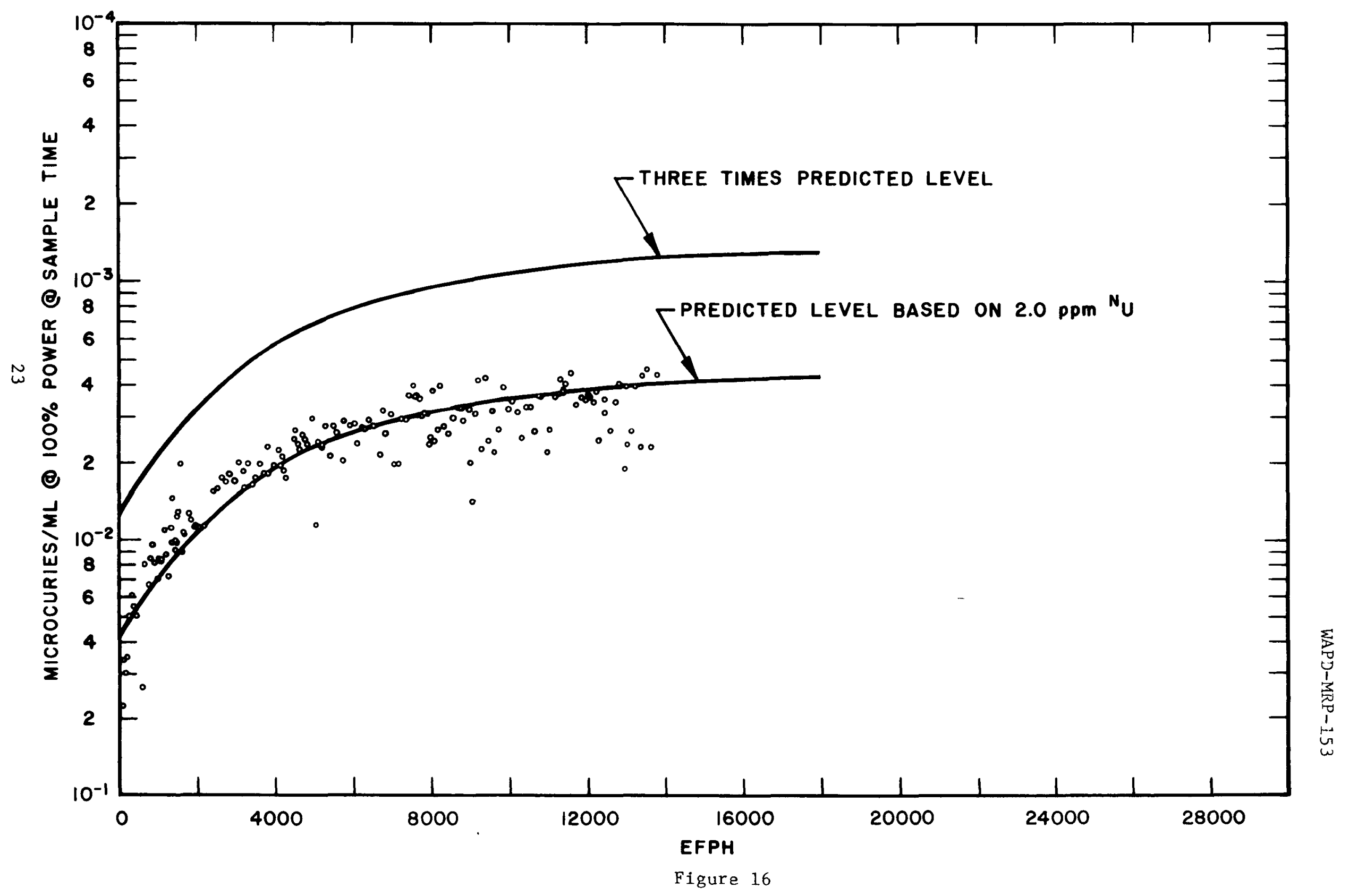


LWBR IODINE-I33 ACTIVITY AS A FUNCTION OF CORE DEPLETION

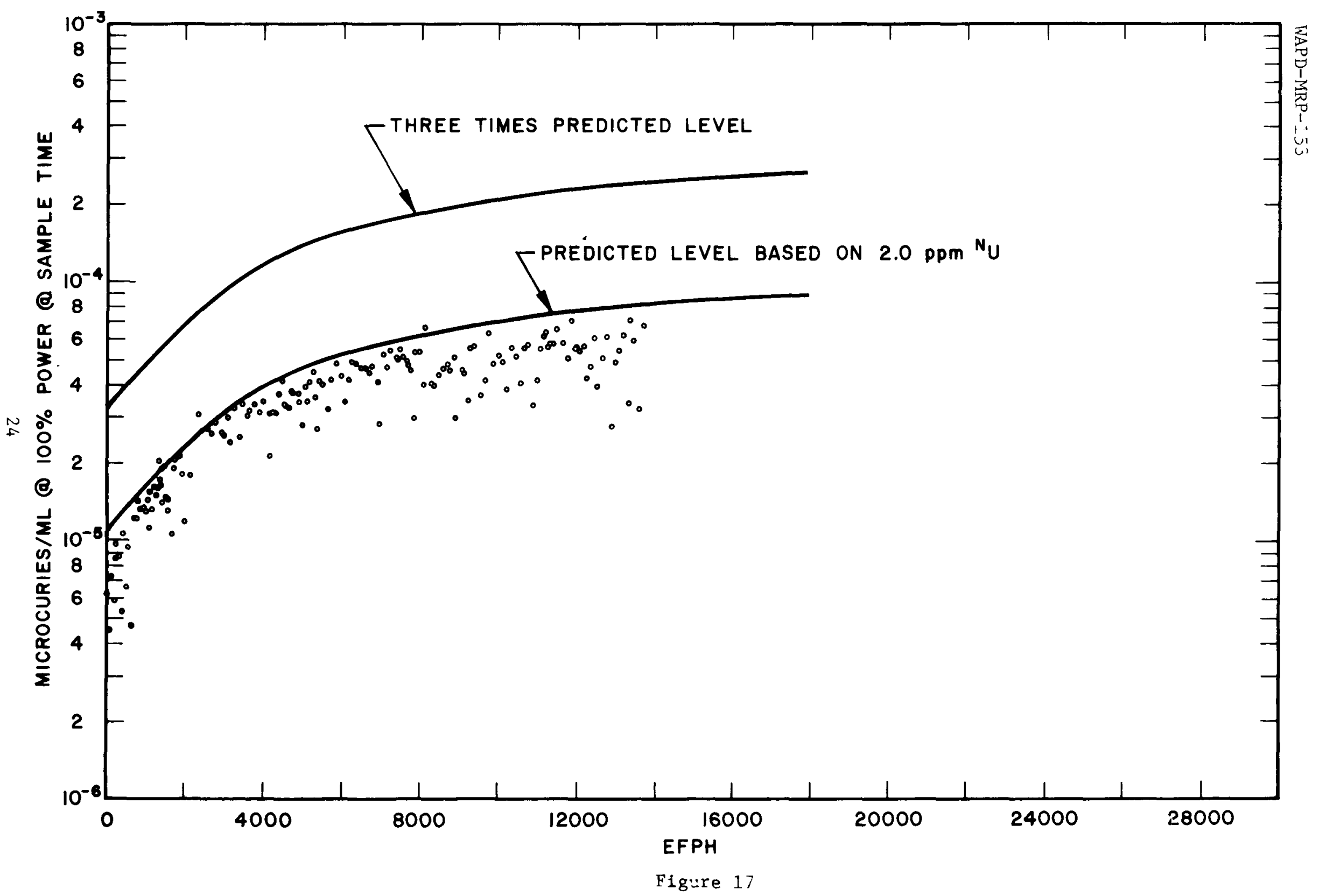


G. LWBR Core Defueling and Shipping Program

The objective of the LWBR Core Defueling and Shipping Program is to remove the LWBR core fuel modules from the reactor and transport them to the Expended Core Facility (ECF) in Idaho to verify LWBR core performance, including an evaluation of breeding performance.

In this report period, fabrication of the following major equipment was completed: the disassembly stand for removing structural components, the refueling seal adapter, a transfer/shipping container for the holddown barrel, and the major tools and lifting adapters for module disassembly and handling. Fabrication continued on the internal structures to support blanket and reflector modules within the shipping containers, and orders were placed for internal structures to support seed modules during shipping, temporary module racks, and shipping equipment including a container servicing system, an underwater containment device, and lifting gear. The design of a cutting machine to sever bolts attaching the lower blanket module structures was completed after successful testing with a prototype machine. The third standardized $M-130$ shipping container was transferred for preparation to ship LWBR modules and work on the first two is in progress.

Preparations were initiated for an operational checkout of defueling equipment and procedures using components retained from the LWBR reactor development tests. The first phase of the checkout will begin in the next report period. Thirty-one detailed defueling and module disassembly procedures were prepared.

H. LWBR Core Evaluation at ECF

The objective of the LWBR Core Evaluation Program to be conducted at the Expended Core Facility is to determine actual LWBR core breeding performance and performance of key core components. The scope and planning for this evaluation program has been described in previous reports (see WAPD-MRP-152).

In this report period, orders were placed for the support structures upon which the large underwater Module Disassembly Apparatus and Cut-Off Systems will sit. The mechanical design was finalized for the Module Disassembly Apparatus and fabrication of the base and table structures for both the machines was started. Detailed designs were completed for fuel storage racks and module stabilization clamps and procurement actions initiated. Most of the detailed designs were completed for hardware required to handle as-received modules and detailed design was initiated on fixtures which will be used to position the modules on the large cutting machines.

A prototype rod removal system was procured and assembled at Bettis. A11 systems are being checked out and operational testing experience 
WAPD-MRP-153

H. is being factored into the final design of the production unit. Similarly, a mockup of the ECF hot cell and operating gallery has been constructed at Bettis, and preparations are in progress to install the Production Irradiated Fuel Assay Gage into the mockup for functional and operational checkout of the assay system. The design of the gage itself has been completed and most components including the major structures have been placed on order. An Electric Discharge Machining power supply has been delivered for use in testing at Bettis, and the detailed designs of components for a prototype Cut-Off System have been partially completed. 


\section{Missing Page from Original Document}


WAPD-MRP-153

LWBR CORE PARAMETERS (cont'd)

UNIT QUANTITY

2. Reactor Core

a. General

Type

Pressurtzed 11ght water moderated and cooled seed and blanket.

Core helght

ft

8.7

Mean Core Diameter

ft

7.5

Fuel Material

Movable Seed

Stationary Blanket

Reflect or Blanket

Fuel loading (Thorium and

Uranium Metric Tons)

Fuel cladding material

Seed, blanket, and

Reflector

21rcaloy -4 , low

Hafnium

Coolant Flow Passes

1

Lifetime

EFPH

$\mathrm{u}^{233} \mathrm{O}_{2}-\mathrm{ThO}_{2}$;

with $\mathrm{ThO}_{2}$ end

reflectors

$\mathrm{u}^{233} \mathrm{O}_{2}-\mathrm{Th} \mathrm{O}_{2}$;

with $\mathrm{ThO}_{2}$ end

reflectors

$\mathrm{ThO}_{2}$

About 42

Fissile Inventory Ratio

(expected end of l1fe)

b. Seed Region

Type of assembly

Rods

Full fuel length

In.

104

Active fuel length

$1 n$.

84 
WAPD-MRP-153

APPENDIX A

LWBR CORE PARAMGEEERS (cont 'd)

UNIT

QUANTITY

Number of fuel modules

12

Number of fuel rods/module

619

Total number of fuel rods

7428

Rod diameter $\left(68^{\circ} \mathrm{F}\right)$

in.

0.306

Rod pitch $\left(68^{\circ} \mathrm{F}\right)$

$\left(531^{\circ} \mathrm{F}\right)$

1n.

0.369

1n.

0.370

Heat transfer area

$f t^{2}$

5,184

c. Regular and Power Flattening Blanket Reglons

Type of assembly

Full fuel length

Active fuel length
Type

Number

Number of fuel rods/module*

Total number of fuel rods**

Rod dlameter $\left(68^{\circ} \mathrm{F}\right)$, In.

Rod pitch $\left(68^{\circ} \mathrm{F}\right), 1 \mathrm{n}$. $\left(531^{\circ} \mathrm{F}\right)$, In.

Heat Transfer Area, $\mathrm{ft}^{2}$

Type I modules

Type II modules

Type III modules 1n.

1n.

Regular Blanket

\section{I}

3

$\begin{array}{lll}444 & 261 & 187\end{array}$

3234

0.5715

0.630

0.6317

III

6

Rods

104

84

Power Flattening Blanket

0.630

0.6317

Regular Blonket

Power Flattening Blanket

1733

1022

1464
II

3

303

3581

0.5275

1091

III

\section{6}

446

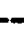

3216

* Includes flux thimble locations

**Excludes flux thimble locations

A-3 
WAPD-MRP -153

\section{APPENDIX A}

LWBR CORE PARAMETERS (cont'd)

UNIT

d. Reflector Blanket Reglons

Type of assembly

Fuel length

Fuel module types

Number of each type

Number of fuel rods/module

Total number of fuel rods

Rod diameter $\left(68^{\circ} \mathrm{F}\right)$

Rod pitch $\left(68^{\circ} \mathrm{F}\right)$

$\left(531^{\circ} \mathrm{F}\right)$

Heat transfer area, $\mathrm{ft}^{2}$

3. Reactor Control and Protection

Type

Number of control elements

Control element speed range

Design maximum reactivity

insertion rate

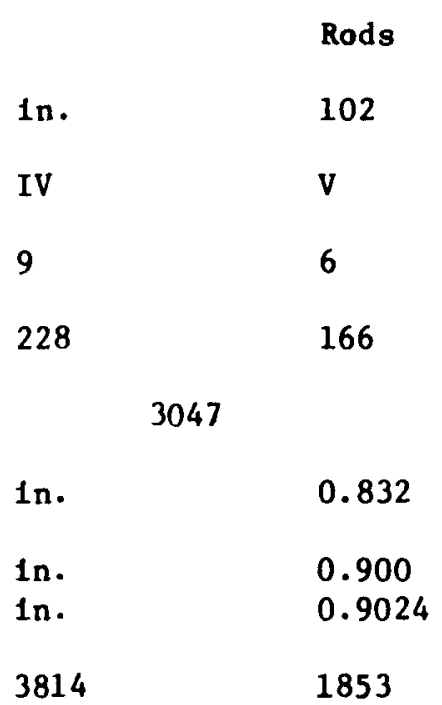

Negative fuel
temperature
coefflclent,
negative moderator
temperature
coeff Iclent, and
movable fuel
control elements

12

$\mathrm{In} / \mathrm{min}$. $\quad 0.5$ to 4.2

$\Delta K /$ sec. $\quad 1.1 \times 10^{-4}$ 
WAPD-MRP -153

LWBR CORE PARAMETERS (cont'd)

UNIT

4. Core Thermal/Hydraul1c Design

Total coolant flow

Total seed flow

Total blanket flow

Total reflector blanket flow

BIF system and leakage flow

Coolant Inlet temperature

Coolant extt temperature

Average coolant temperature

Coolant temperature rise

Coolant pressure
$1 \mathrm{~b} / \mathrm{hr}$

$1 \mathrm{~b} / \mathrm{hr}$

$\mathrm{lb} / \mathrm{hr}$

$\mathrm{lb} / \mathrm{hr}$

$1 \mathrm{~b} / \mathrm{hr}$

$\bullet \mathbf{E}$

${ }^{\circ} \mathbf{F}$

${ }^{\circ} \mathbf{F}$

${ }^{\circ} \mathbf{F}$

pa1a
QUANTITY

$30.90 \times 10^{6}$

$7.74 \times 10^{6}$

$15.66 \times 10^{6}$

$2.90 \times 10^{6}$

$4.60 \times 10^{6}$

520

542

531

22

1815 